\title{
Research article Protein difference among the leaf explants determined for shoot regeneration and callus growth in Mulberry (Morus indica L.)
}

\author{
D.S. Vijaya Chitra1*, Bhaskarrao Chinthapalli1, and G. Padmaja ${ }^{2}$ \\ 1Present Address: College of Natural Sciences, Department of Biology, Arba Minch University, \\ Arba Minch, P.O. Box 21, Ethiopia \\ ${ }^{2}$ Department of Plant Sciences, School of Life Sciences, University of Hyderabad, \\ Prof. C.R Rao Road, Gachibowli, Hyderabad, Andhra Pradesh 500046. \\ ${ }^{*}$ Corresponding author email :dsvijaya.chitra@gmail.com
}

A comparison of protein profiles of leaves during different stages of shoot and callus induction showed similarities as well as differences in the expression of proteins. A protein of $39 \mathrm{kDa}$ was expressed in low levels in leaf explants and increased in intensity during induction of shoot organogenesis in both the cultivars. Analysis of protein patterns during organogenesis and callus proliferation from leaves by two dimensional gel analysis revealed the separation of $39 \mathrm{kDa}$ protein into four spots during organogenesis with $\mathrm{pI}$ values ranging from 4.2-5.8. However, the isoforms of $39 \mathrm{kDa}$ protein with $\mathrm{pI}$ values of 4.2 and 5.8 were highly expressed in callus of M-5 cultivar in contrast to S-36 cultivar where only one isoform with pI value of 4.2 was detectable. The analysis of protein synthesis in different stages of development in the cultures may acts as markers to differentiate the group of specific isoforms.

Key words: Protein profiles, S-36 cultivar, M-5 cultivar, organogenesis, callus proliferation

Mulberry is an indispensable crop for the sericulture industry as it serves as the exclusive source of feed for silkworms (Bombyx mori L.). Regeneration of plants via de novo shoot formation is necessary for application of gene transfer technology and for screening plants for somaclonal variation. In vitro plant regeneration via adventitious shoot formation has been reported from hypocotyls, cotyledons (Kim et al., 1985), stem segments (Narayan et al., 1989; Jain and Datta, 1992), leaf explants (Oka and Ohyama, 1981; Mhatre et al., 1985; Machii, 1992; Chitra and Padmaja, 1999, 2002).

The use of the in vitro technology has made significant contribution to our understanding of the processes of organized development namely de novo organogenesis and somatic embryogenesis (Thorpe, 1993). Though regeneration has been reported in a number of plant species in cultures, the regulatory mechanism(s) underlying morphogenesis still remains one of the most mysterious and challenging problems of biology (Flick et al., 1983). Proteins are valuable indicators of differentiation and have been used in taxonomy, as genetic markers and for identifying specific stages of plant development. Variation in protein patterns in differentiating and nondifferentiating tissues has been reported in Oryza sativa L. (Chen and Luthe, 1987) in 
barley and sugarcane (Ramagopal, 1989, 1994) and in Nicotiana tabacum (Garcia et al., 1992). In the present study, protein differences associated with leaf tissues during different stages of callogenesis and shoot organogenesis have been studied.

\section{Materials and Methods}

Leaves with or without petiole derived from the sterile shoot cultures of mulberry were used as the experimental source. Shoot cultures were established by culturing axillary buds obtained from three year old plants of Morus indica cultivar M-5, S-13, S-36 and Morus alba cultivar China White. The excised axillary buds where surface sterilized in $70 \%$ alcohol for one min followed by $0.1 \%$ mercuric chloride for 15 min. The axillary buds were finally rinsed for 4 to 5 times in sterile distilled water with 5 min duration each. The sterilized axillary bud of cultivars M-5, and S-36 were cultured on $0.3 \mathrm{mg} / 1$ 2,4 D supplemented in MS medium (Murashige and Skoog, 1962; Chitra and Padmaja, 2002; 2005; Chitra et al., 2016). Lea $\uparrow$ ves were cultured with either abaxial or adaxial side in contact with the medium. The appearance of adventitious buds from the leaf was taken into consideration for calculating the shoot organogenesis from the leaves. For all the experiments on induction of axillary bud sprouting, shoot multiplication and root induction from shoots, the cultures were maintained at 25 \pm $2^{\circ} \mathrm{C}$ under a $16 \mathrm{hr}$ photoperiod with a photosynthetic photon flux density (PPFD) of $83.6 \mu \mathrm{E} \mathrm{m} \mathrm{m}^{-2} \mathrm{~s}^{-1}$ provided by white fluorescent tubes.

\section{Samples for SDS-PAGE}

Protein profiles during callus proliferation from the leaves:

Leaves of $1-4 \mathrm{~cm}$ derived from the in vitro multiplied shoots were cultured on MS medium with $2.0 \mathrm{mg} / 1$ 2,4-D for induction of callus. Protein profiles were analyzed from the samples collected at explant stage $\left(1^{\text {st }}\right.$ sample), swelling of the explant (2nd sample), slight initiation of callus (3rd sample) and complete proliferation of callus ( $4^{\text {th }}$ sample).

Protein profiles during shoot organogenesis from leaves:

For studying the changes in protein profiles associated with shoot organogenesis, leaves of 1-4 cm derived from the in vitro multiplied shoots were cultured on MS medium with $2.0 \mathrm{mg} / 1 \mathrm{BAP}$ and the samples were collected at explant stage $\left(1^{\text {st }}\right.$ sample), swelling of the explant (2nd sample), induction of shoot buds ( $3^{\text {rd }}$ sample) and induction of shoots of $0.5-1.0 \mathrm{~cm}$ ( $4^{\text {th }}$ sample). The basal region of the leaves eliminating the apical portion (1 ${ }^{\text {st }}$ sample) or the basal region with the differentiated shoots was used for sampling.

Extraction of protein and gel
electrophoresis: All the samples mentioned above were weighed $100 \mathrm{mg}$ each and was extracted $50 \mathrm{mM}$ Tris $\mathrm{HCl}$ buffer ( $\mathrm{pH}$ 5.7) containing $5 \mathrm{mM} \mathrm{MgCl}, 2 \mathrm{mM} \mathrm{K} \mathrm{K}_{2} \mathrm{HPO}_{4}$, 1mM EDTA, $5 \mathrm{mM}$ DTT, $2 \mathrm{mM} \mathrm{KH} \mathrm{PO}_{4}, 5$ $\mathrm{mM}$ DTT, 2\% PVP, 20\% glycerol, 10mM NaF, $10 \mathrm{mM} \beta$-mercaptoethanol and 2mM PMSF. After homogenization, the samples were centrifuged at $4^{\circ} \mathrm{C}$ centigrade for $20 \mathrm{~min}$ at $12,000 \mathrm{rpm}$. The supernatant was taken and soluble protein content was estimated by Lowry's (1951) method with minor modifications. Bovine serum albumin (BSA Fraction V) was used as a standard protein (5-50 $\mu \mathrm{g} / \mathrm{ml})$; absorbance of the samples was recorded at $750 \mathrm{~nm}$. Sodium dodecyl sulphate polyacrylamide gel electrophoresis was performed following the method of Laemmli (1970) with minor modifications. The separation of proteins was performed in $5 \%$ stacking gel and $10 \%$ resolving gel. Medium range molecular weight marker (Bangalore Genei Pvt. Ltd.) was used for calibration. 
Two-dimensional polyacrylamide gel electrophoresis:

Proteins were separated by isoelectro focusing in $0.3 \times 10 \mathrm{~cm}$ long tubes, according to the method of O'Farrel (1975). The second dimension slab gel for molecular weight was performed by SDS-PAGE as described previously and the gels were silver stained according to the method of Blum et al. (1987).

\section{(a) Isoelectric Focusing (First dimension):}

Polyacrylamide used was 30\% $(1.8 \%$ bis acrylamide as cross linker) in tube gels $(0.35 \times 8 \mathrm{~cm})$ in the presence of $9.5 \mathrm{M}$ urea, $10 \%$ Nonidet $\mathrm{P}-40$ and $2 \%$ ampholines $(\mathrm{pH} 4$ 6 range, $1.6 \%$ and $\mathrm{pH} 3.5-10$ range, $0.4 \%$ ) for the first dimension. The gels were pre-run at 200 volts for $15 \mathrm{~min}, 300$ volts for $30 \mathrm{~min}$ and 400 volts for $30 \mathrm{~min}$ with $0.03 \mathrm{M}$ Sodium hydroxide $(\mathrm{NaOH})$ as cathodic solution and $0.01 \mathrm{M}$ Phosphoric acid $\left(\mathrm{H}_{3} \mathrm{PO} 4\right)$ as anodic solution. After pre-run anodic and cathodic solutions were replaced with fresh solutions. Approximately 50 $\mu \mathrm{g}$ of protein in the sample buffer $(9.5 \mathrm{M}$ urea, $2 \%$ ampholines, $10 \% \mathrm{w} / \mathrm{v}$ Nonidet P-40 and 5\% $\beta$-mercaptoethanol) was loaded on the gels. The protein samples were overlaid with $10 \mu \mathrm{l}$ of $8 \mathrm{M}$ urea followed by $0.03 \mathrm{M} \mathrm{NaOH}$. One tube gel was run without protein sample for measuring the $\mathrm{pH}$. Electrophoresis was carried out at 600 volts for $12 \mathrm{hr}, 700$ volts for $1 \mathrm{hr}$ and finally for $1 \mathrm{hr}$ at 800 volts. The gels were extruded out of the tube and equilibrated in the equilibration buffer $(0.0625$ Tris $\mathrm{HCl}, \mathrm{pH}$ 6.7 with $10 \%$ glycerol, $0.005 \mathrm{M}$ DTT and $2.3 \%$ SDS) for $1 \mathrm{hr}$, thereafter the gels were removed immediately and used for second dimension or for $\mathrm{pH}$ measurement. The gels were stored at $-70^{\circ} \mathrm{C}$ until further use.

\section{(b) Second Dimension:}

The second dimension was performed in a discontinuous SDS-PAGE as previously described and silver stained. The IEF gels were placed on stacking gel and sealed with $1 \%$ agarose made in equilibration buffer. The standard markers were loaded in corner side of the gels. The gels were removed and silver stained.

\section{(c) Measurement of $\mathrm{pH}$ :}

The isoelectric focused gels were cut into $1 \mathrm{~cm}$ pieces and placed in individual test tubes containing $1.0 \mathrm{ml}$ of distilled water. The test tubes were vortexed and kept overnight at room temperature. The $\mathrm{pH}$ was measured with $\mathrm{pH}$ meter.

\section{(d) Silver Staining:}

The proteins were detected in the gel by silver staining procedure according to Blum et al. (1987).

\section{Results}

SDS-PAGE analysis during callus proliferation and shoot organogenesis from leaf explants:

In an effort to identify a developmental marker specific to shoot organogenesis, protein profiles of different stages of shoot organogenesis were compared with different stages of callus proliferation from leaf explants of M-5 and S36 cultivars. Leaf explants cultured on MS medium with $2.0 \mathrm{mg} / 12,4-\mathrm{D}$ produced callus whereas those cultured on $2.0 \mathrm{mg} / 1 \mathrm{BAP}$ underwent shoot organogenesis. SDS-PAGE analysis was made from the protein extracted from the leaves at different stages of callus proliferation and shoot organogenesis. Analysis of protein profiles during callus proliferation and shoot organogenesis in M-5 cultivar revealed high expression of $49 \mathrm{kDa}$ protein in leaf explants which decreased in intensity following culture. Proteins of 103, 94, 82 and $76 \mathrm{kDa}$ were not detectable in leaf explants but were seen as clear bands during shoot organogenesis. These proteins appeared at high intensity in early stages of callus induction but decreased in intensity when there was complete proliferation of the callus. There was an increase in intensity of 
$39 \mathrm{kDa}$ protein during the induction of shoot organogenesis whereas the intensity of this protein was very low in the leaf explants. This protein increased in amounts during the initial stages of callus proliferation and was present in lower amounts in leaf derived callus. A protein of $25 \mathrm{kDa}$ was specifically expressed during callus proliferation and

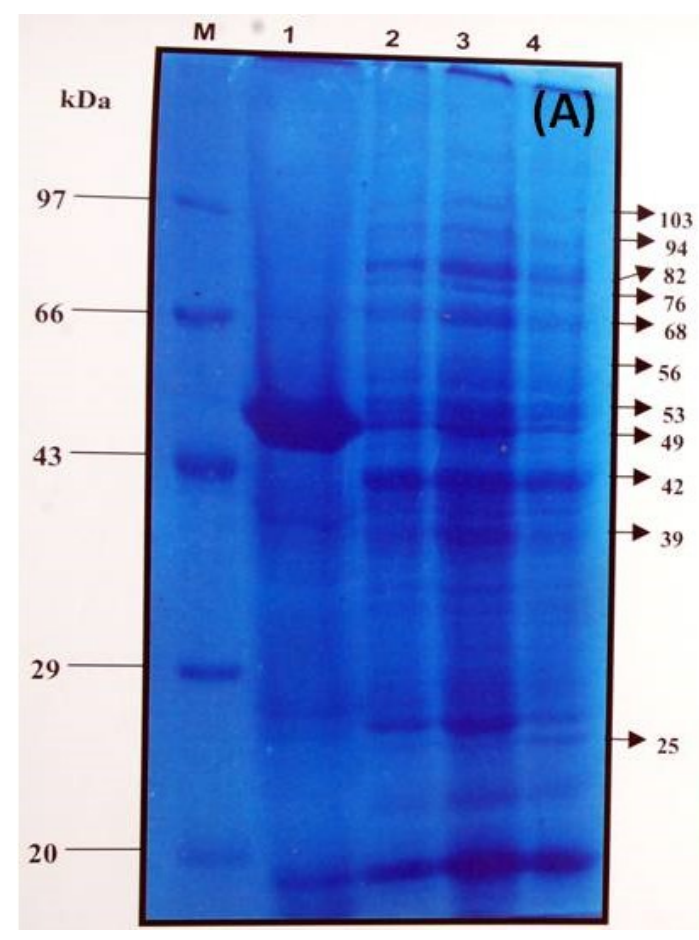

was not detectable in leaf explants or during induction of shoot organogenesis. A significant number of proteins with MW 68, 56, 53 and 42 were common to callus proliferation and shoot organogenesis and appeared at more or less at the same level during all stages of culture (Fig. 1A and B).

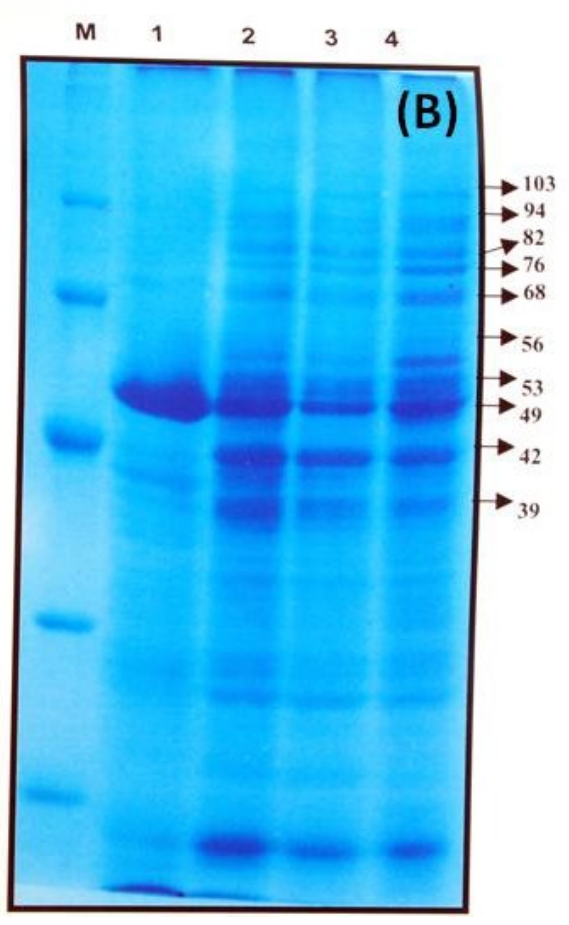

Fig. 1: (A). SDS-PAGE gel of protein extracts prepared from leaf explants of M-5 cultivar at different stages of callus proliferation and stained with coomassie blue. Lane 1 : Molecular weight marker Lane 2 : Leaf explant ( 0 day) Lane 3 : Swelling of the explants Lane 4 : Initiation of callus from leaf explants Lane 5 : Callus derived from leaf explants. Arrows point to the bands of interest. (B). SDS-PAGE gel of protein extracts prepared from leaf explants of M-5 cultivar at different stages of shoot organogenesis and stained with coomassie blue Lane 1: Molecular weight marker Lane 2 : Leaf explant (0 day) Lane 3 : Swelling of the explants Lane 4 : Induction of shoot buds from leaf explants Lane 5 : Development of shoots $(0.5-1.0 \mathrm{~cm})$ from the explants. Arrows point to the bands of interest.

A protein of MW $49 \mathrm{kDa}$ was present in abundance in leaf explants and decreased in intensity during induction of shoot organogenesis in S-36 cultivar. Proteins of $103 \mathrm{kDa}$ and $94 \mathrm{kDa}$ were not detectable in leaf explants and expressed at a low intensity during all the stages of callus proliferation and shoot organogenesis. Differences in staining intensities were noticed with respect to 55 and $53 \mathrm{kDa}$ proteins which were expressed at high levels in the $4^{\text {th }}$ stage of shoot organogenesis whereas the intensity of these proteins was low in the corresponding stages of callus proliferation. Proteins of 
MW 125 and $68 \mathrm{kDa}$ were expressed at the same intensity at all stages of callus proliferation and leaf organogenesis. The intensity of 82 and $76 \mathrm{kDa}$ proteins increased at the $2^{\text {nd }}$ stage of shoot organogenesis and callus proliferation and continued to express at the same level during the subsequent stages of culture. On the contrary, a protein of $39 \mathrm{kDa}$ was expressed in low levels in leaf explants and increased in intensity during induction of shoot organogenesis. However, this protein increased in intensity during the initial stages of callus induction and appeared faintly when the leaf explants completely developed into callus (Fig. 2A and $B$ ).

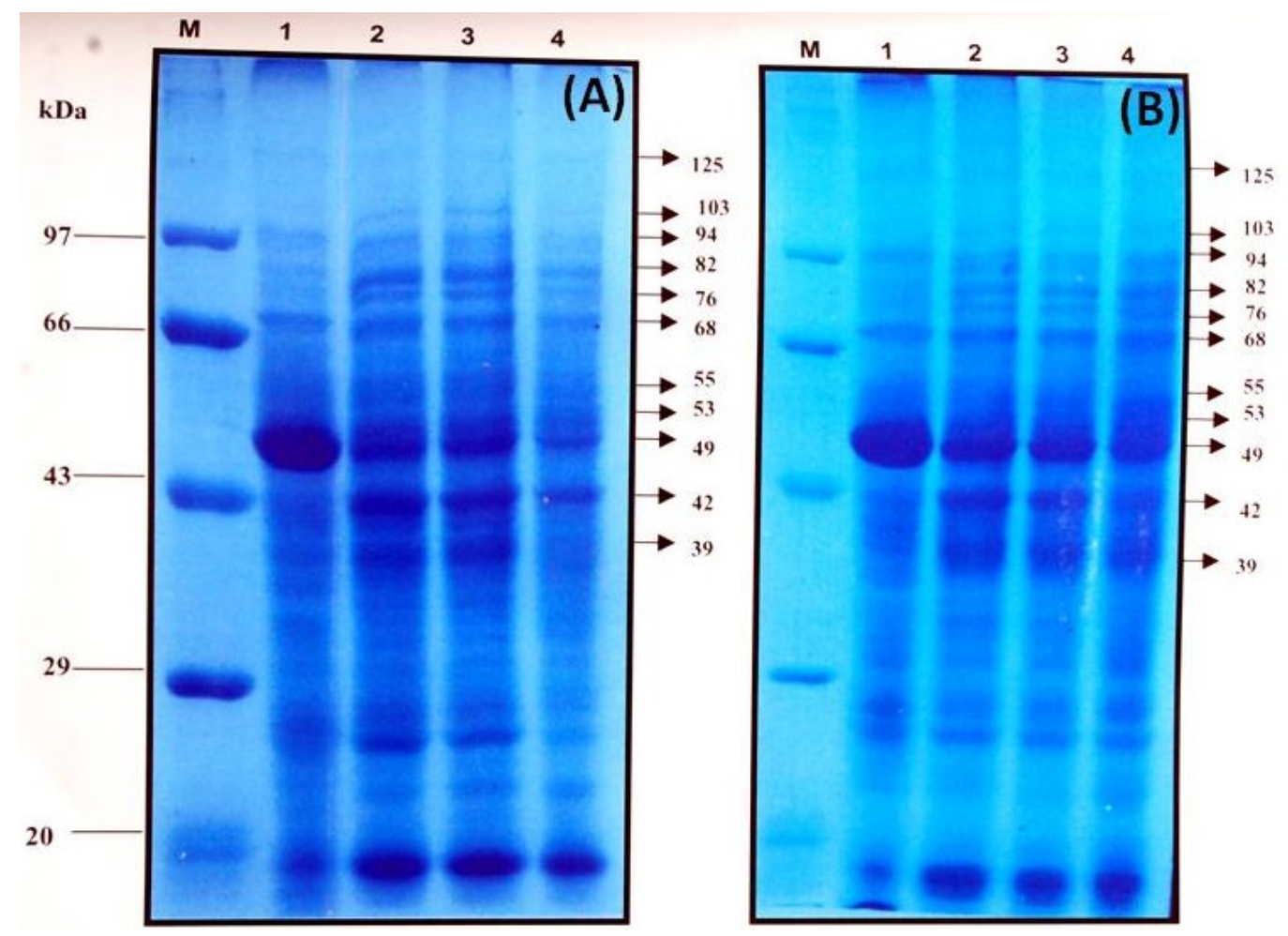

Fig. 2: (A). SDS-PAGE gel of protein extracts prepared from leaf explants of S-36 cultivar at different stages of callus proliferation and stained with coomassie blue. Lane 1 : Molecular weight marker; Lane 2 : Leaf explant (0 day); Lane 3 : Swelling of the explants; Lane 4 : Initiation of callus from leaf explants; Lane 5 : Callus derived from leaf explants; Arrows point to the bands of interest. (B). SDS-PAGE gel of protein extracts prepared from leaf explants of S36 cultivar at different stages of shoot organogenesis and stained with coomassie blue. Lane 1 : Molecular weight marker; Lane 2 : Leaf explant (0 day); Lane 3 : Swelling of the explants; Lane 4 : Induction of shoot buds from leaf explants; Lane 5 : Development of shoots $(0.5-1.0 \mathrm{~cm})$ from the explants. Arrows point to the bands of interest.

Two- dimensional analysis of protein during organogenesis and callus induction:

SDS-PAGE analysis during callus proliferation and shoot organogenesis from leaf explants revealed major differences in the expression of $39 \mathrm{kDa}$ protein which expressed in relatively higher levels during final stages of shoot organogenesis whereas the relative amount of this protein was low in callus derived from leaf explants. To more precisely identify differences in the specific proteins during organogenesis and callus 
proliferation from leaf explants, the protein extracts of these samples were analysed by two-dimensional gel electrophoresis followed by highly sensitive silver staining. During the final stages of shoot organogenesis, $39 \mathrm{kDa}$ protein appeared intensely and was expressed in four isoforms with pI values ranging from 4.2 to 5.8 in both the cultivars. However, $39 \mathrm{kDa}$ protein was expressed in two isoforms with pI values of 4.2 and 5.8 were observed in leaf derived callus of M-5 cultivar in contrast to S-36 cultivar where only one isoform with $\mathrm{pI}$ value of 4.2 was detectable. A protein of MW $62 \mathrm{kDa}$ was more expressed in the leaf explants of S-36 cultivar than in M-5 cultivar with $\mathrm{pI}$ values ranging from 4.3-6.5 and 4.25.4 , respectively. This protein was expressed during shoot organogenesis with $\mathrm{pI}$ values of 4.6 and 5.0 in M-5 cultivar and pI value of 4.3 in S-36 cultivar whereas callus of both the cultivars showed very faint expression. SDSPAGE analysis revealed the presence of 49 $\mathrm{kDa}$ protein at a high intensity in leaf explants and decreased in intensity during the process of de-differentiation and shoot differentiation. 2-D analysis revealed that protein of $49 \mathrm{kDa}$ protein was expressed with pI values ranging from 3.0-4.8 in leaf explants of M-5 cultivar whereas this protein separated into isoforms with $\mathrm{pI}$ values ranging from 4.8-5.6 during shoot organogenesis and $\mathrm{pI}$ values ranging from 4.5-5.8 during callus proliferation. In S-36 cultivar, $49 \mathrm{kDa}$ protein was expressed with isoforms ranging from 3.0-4.5 in the leaf explants, whereas isoforms with $\mathrm{pI}$ values ranging from 4.5-5.3 were observed in the final stages of shoot organogenesis and callus proliferation. The expression of 32 $\mathrm{kDa}$ protein was more intense in S-36 cultivar in comparison to M-5 cultivar with $\mathrm{pI}$ values ranging from 3.5-5.4 and 3.2-4.2, respectively in the leaf explants.

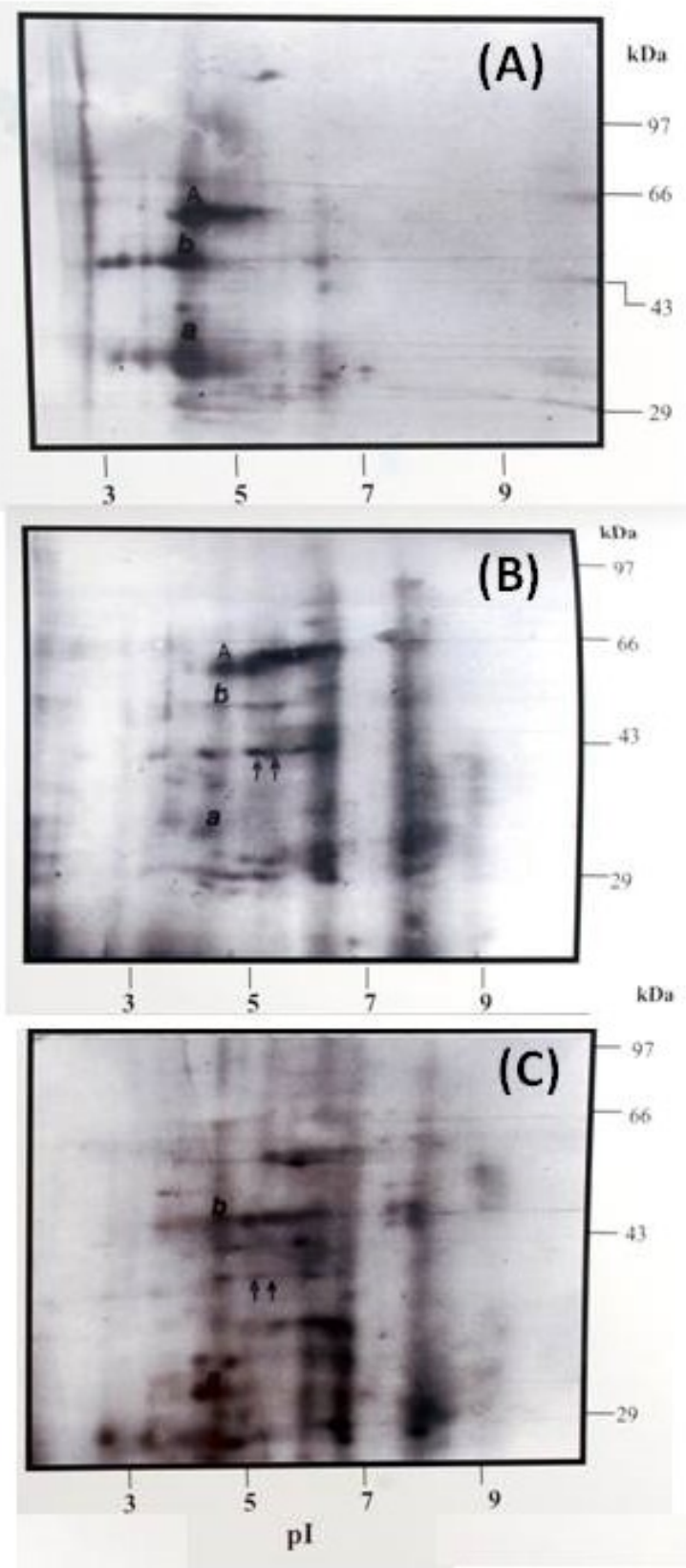

Fig. 3: Two dimensional electrophoretic analysis of the protein extracted from leaf explants of M-5 cultivar during shoot organogenesis and callus proliferation. (A). Leaf explants: A - $62 \mathrm{kDa}$ protein; a - $49 \mathrm{kDa}$ protein; b - $32 \mathrm{kDa}$ protein. (B). Development of shoots from leaf explants: A - $62 \mathrm{kDa}$ protein; a - $49 \mathrm{kDa}$ protein; b - $32 \mathrm{kDa}$ protein; $\quad \uparrow \uparrow 39 \mathrm{kDa}$ protein (C). Callus derived from leaf explants: a - $49 \mathrm{kDa}$ protein; $\mathrm{b}$ - $32 \mathrm{kDa}$ protein; $\uparrow \uparrow 39 \mathrm{kDa}$ protein. 

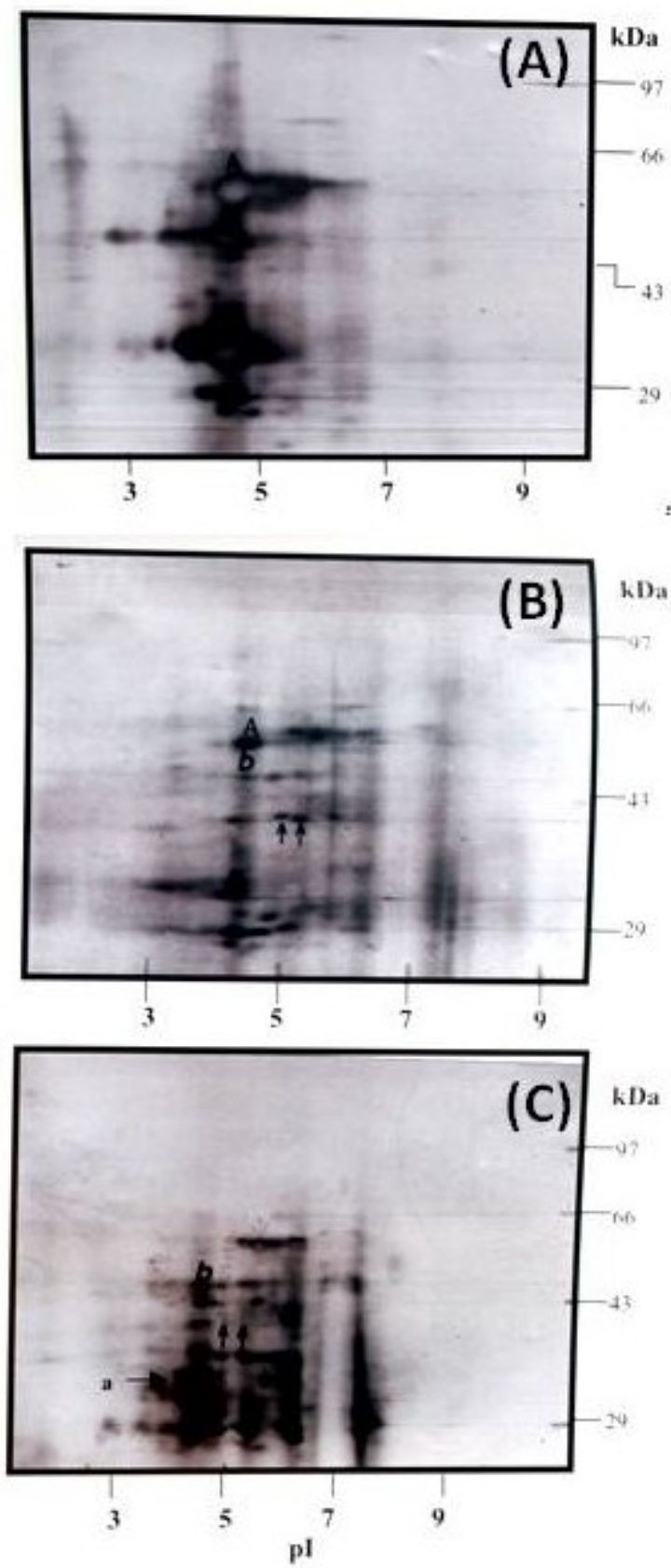

Fig. 4: Two dimensional electrophoretic analysis of the protein extracted from leaf explants of S-36 cultivar during shoot organogenesis and callus proliferation. (A). Leaf explants: A - 62kDa protein; a - $49 \mathrm{kDa}$ protein; b - $32 \mathrm{kDa}$ protein (B). Development of shoots from leaf explants: A - 62kDa protein; a - $49 \mathrm{kDa}$ protein; b - $32 \mathrm{kDa}$ protein; $\uparrow \uparrow 39 \mathrm{kDa}$ protein (C). Callus derived from leaf explants: $\mathrm{a}-49 \mathrm{kDa}$ protein; $\mathrm{b}-32$ $\mathrm{kDa}$ protein; $\uparrow \uparrow 39 \mathrm{kDa}$ protein
During the final stages of shoot organogenesis, $32 \mathrm{kDa}$ protein was expressed with a pI value of 4.2 in M-5 and S-36 cultivars whereas this protein was expressed with $\mathrm{pI}$ values of 4.5-6.2 and 4.5-5.3 in the callus of M-5 and S-36 cultivars, respectively. Most of the proteins in the leaf explants were found to be towards the acidic side in both the cultivars whereas in the final stages of callus proliferation and shoot organogenesis, the proteins were distributed from acidic to neutral side (Fig. 3 and 4).

\section{Discussion}

Growth and differentiation involve the metabolism of various proteins at different stages. Identification of such proteins associated with somatic embryogenesis and organogenesis is important to elucidate the biochemical and molecular mechanisms underlying the process. Many reports have appeared on the quantitative and qualitative differences in protein profiles of embryogenic and non embryogenic calli in a variety of plants (Sung and Okimoto 1981, Choi and Sung, 1984, de Veries et al., 1988 in case of carrot; Chen and Luthe, 1987 for rice; Stirn and Jacobson, 1987 for pea and Hahne et al., 1988 for orchard grass). However, no considerable effort has been made to study the biochemical aspects particularly the protein profiles with respect to organogenesis or embryogenesis in mulberry.

In the present study, the protein profiles during different stages of callus proliferation and shoot organogenesis from leaf explants were studied to identify markers specific for de-differentiation and shoot differentiation. In the leaf cultures of mulberry, the cells either proliferate as callus or differentiate into shoots. These cells undergo the process of de-differentiation when the auxin 2,4-D $(2.0 \mathrm{mg} / \mathrm{l})$ is used in the medium whereas in the presence of BAP $(2.0 \mathrm{mg} / \mathrm{l})$, direct shoot regeneration is 
observed. In order to determine whether the induction of callus or shoot regeneration induced from leaf explants by manipulation of growth regulators in the culture media is correlated with the biochemical events, equal amount of proteins were extracted from the above cultures and separated on SDS-PAGE. A comparison of the protein profiles of leaves during different stages of callus proliferation and shoot induction showed similarities as well as differences in the expression of few proteins. A $49 \mathrm{kDa}$ protein was predominant in leaf explants of $\mathrm{M}-5$ and S-36 cultivars and decreased in intensity during the process of callus proliferation and shoot organogenesis. This possibly represents the product of gene concerned with leaf physiology. A protein of $39 \mathrm{kDa}$ was expressed in low levels in leaf explants and increased in intensity during induction of shoot organogenesis in both the cultivars. However, this protein increased in intensity during the initial stages of callus induction and appeared faintly when the leaf explants completely developed into callus. In contrast, in M-5 cultivar, a protein of $25 \mathrm{kDa}$ specifically expressed during callus proliferation and was not detectable during shoot organogenesis, and might be associated with unorganized growth. However, protein characteristic exclusively to callus proliferation could not be detected in S-36 cultivar.

Protein changes have previously been used as markers to delineate stages in axillary bud development in pea (Stafstrom and Sussex, 1988), and to identify the time of bud regeneration in detached pine cotyledons (Villalobos et al., 1984). A significant number of the new proteins were common to callus proliferation and shoot organogenesis in M-5 cultivar and were expressed at relatively constant level throughout the culture period. They possibly represent the products of basic metabolic "house-keeping' genes that are components of normal metabolic functions such as cell division and stress responses. Sung and Okimoto (1983) showed that undifferentiated cells produce 'callusspecific' proteins, and that these 'callusspecific' and 'embryonic' proteins are coordinately regulated. The ability of conifer cotyledons to form shoots in the presence of benzyladenine was distinguished based on their protein profiles (Ellis and Judd, 1987). Chen and Luthe (1987) reported that $45 \mathrm{kDa}$ polypeptide consistenly increased in nonembryogenic (NE) rice (Oryza sativa L.) calli when it was subcultured on regeneration medium for 9-12 days. There was a little change in the abundance of the $45 \mathrm{kD}$ polypeptide group in embryogenic calli which suggested that it may be correlated with unorganized growth in NE calli. Guru et al. (1999) studied the protein pattern of differentiating and non-differentiating calli using SDS-PAGE in two varieties of chickpea viz., BG 267 (kabuli) and BG 362 (desi). The study demonstrated the influence of genotype on the proteins related to differentiation and the role of these proteins in morphogenesis in chickpea. A protein band of molecular weight around $50 \mathrm{kDa}$ was identified in the differentiating calli of the kabuli variety, which was absent in the non-differentiating calli.

One-dimensional system reveals only quantitative differences as multiple bands whereas two-dimensional analysis shows the qualitative contributions of different isoforms to each protein species. The 2-D analysis performed during callus proliferation and shoot organogenesis from leaves revealed the separation of $49 \mathrm{kDa}$ into various isoforms with $\mathrm{pI}$ values ranging from 3.0-4.8 in M-5 cultivar and 3.0-4.5 in S36 cultivar. With respect to shoot organogenesis, $39 \mathrm{kDa}$ protein is of particular interest as it is more abundant in the final stages of shoot organogenesis in $\mathrm{M}$ 5 and S-36 cultivars and thus can be correlated with shoot differentiation. A few proteins showed differential expression 
during shoot organogenesis and callus proliferation from the leaves of M-5 and S-36 cultivars. In M-5 and S-36 cultivars, $39 \mathrm{kDa}$ protein separated into four spots during shoot organogenesis with $\mathrm{pI}$ values ranging from 4.2-5.8. However, $39 \mathrm{kDa}$ protein was expressed in two isoforms with $\mathrm{pI}$ values of 4.2 and 5.8 in callus of M-5 cultivar in contrast to S-36 cultivar where only one isoform with pI value of 4.2 was detectable. This observation shows that isoforms of 39 $\mathrm{kDa}$ protein vary in expression during callus proliferation and shoot organogenesis in M-5 and S-36 cultivars. Protein with MW $62 \mathrm{kDa}$ was more expressed in the leaf explants of S36 cultivar than in M-5 cultivar with $\mathrm{pI}$ values ranging from 4.3-6.5 and $\mathrm{pI}$ values of 4.2-5.4, respectively. This protein was expressed during organogenesis with $\mathrm{pI}$ values of 4.6 and 5.0 in M-5 cultivar and pI value of 4.3 in S-36 cultivar whereas callus of both the cultivars showed very faint expression. This complexity may be the result of post-translational protein modification or of the existence of multiple genes encoding similar but non-identical gene-products, or a combination of the two (Hakman et al., 1990). The function of these proteins is presently unknown, however, they can serve as developmental markers for understanding the process of shoot differentiation in mulberry. Hahne et al. (1988) reported that callus specific proteins were not detected in the leaf (explanting stage), apparently because it is a tissue type without direct equivalent in whole plants and thus not unexpectedly contains unique proteins. Coleman and Ernst (1991) studied the protein differences among internodal stem explants of Populus deltoids that were determined for either shoot regeneration or callus growth by SDS-PAGE and twodimensional PAGE. Three $32 \mathrm{kDa}$ proteins with $\mathrm{pI}$ values of approximately 6.5-7.5 were detected only in callus inducing (cim) and shoot inducing ( $\mathrm{sim}$ ) treatments for which high levels of adventitious shoot regeneration was observed. A $35 \mathrm{kDa}$ protein of approximately pI 7.0 was observed only in the $\mathrm{cim} / \mathrm{sim}$ treatments which resulted in callus determined growth. Similarly, according to Reynolds (1990) using two dimensional gel electrophoresis were identified different sets of proteins associated with development in vitro from total soluble protein and protein labeled in vivo extracted from regenerating and nonregenerating cultures. Our study is the first report to observe the protein profiles during differentiation and de-differentiation in leaf explants of mulberry.

\section{Conflict of interests}

Authors confirm that above provided data do not contain conflict of interests.

\section{Acknowledgements}

We gratefully acknowledge University Grants Commission, New Delhi for providing financial assistance under unassigned grant scheme to carry out this work. DSVC is thankful to University Grants Commission, New Delhi for the award of extended SRF Fellowship.

\section{References}

Blum H, Beier $\mathrm{H}$ and Gross H. J. 1987. Improved silver staining of plant proteins, RNA and DNA in polyacrylamide gels, Electrophoresis, 8: 93-99

Chen L. J and Luthe D. S. 1987. Analysis of proteins from embryogenic and nonembryogenic rice (Oryza sativa L.) calli, Plant Science, 48: 181-188

Chitra D.S.V and Padmaja G. 1999. Clonal propagation of mulberry (Morus indica L. cultivar M-5) through in vitro culture of nodal explants, Scientia Horticulture, 80: 289-298

Chitra D.S.V and Padmaja G. 2002. Seasonal influence on axillary bud sprouting and micropropagation of elite cultivars of mulberry, Scientia Horticulture, 92: 55-68 
Chitra D.S.V and Padmaja G. 2005. Shoot regeneration via direct organogenesis from in vitro derived leaves of mulberry using thidiazuron and 6benzylaminopurine, Scientia Horticulture, 106: 593-602

Chitra D.S.V., Chinthapalli B and Padmaja G. 2016. A comparative study on field performance of micropropagated plants and stem cutting derived plants of S-36 cultivar of Mulberry (Morus indica L.), Research in Biotechnology, 7: 21-27

Choi J. H and Sung Z. R. 1984. Twodimensional gel analysis of carrot somatic embryonic proteins, Plant Molecular Biology Reports, 2: 19-25

Coleman D. G and Ernst S. G. 1991. Protein differences among Populus deltoids internodal stem explants determined for shoot regeneration or callus growth, Plant Science, 75: 83-92

De Vries S. C. Booij H. Janssens R. Vogels R. Saris L. Lo Schiavo F. Terzi M and Van Kammen A. 1988. Carrot somatic embryogenesis depends on the phytochrome/controlled presence of correctly glycosylated extracellular proteins. Genes and Development, 2: 462476

Ellis D. D and Judd R. C. 1987. SDS-PAGE analysis of bud-forming cotyledons of Pinus ponderosa. Plant Cell Tissue and Organ Culture, 11: 57-65

Flick C. E. Evans D. A and Sharp, W. R. 1983. Organogenesis. In: (eds.) Evans, D. A., Sharp, W. R., Ammirato, V. P. and Yamada, Y. Macmillan, New York, 13-81

Garcia, R. B. Walling, L. L and Murashige, T. 1992. Analysis of polypeptides associated with shoot formation in tobacco callus cultures. American Journal of Botany, 79: 481-487

Guru, S. K. Chandra, R. Khetrapal, S. Raj, A and Polisetty, R. 1999. Protein pattern in differentiating explants of chick pea (Cicer arietinum L.), Indian Journal Plant Physiol. 4:147-151
Hahne, G. Mayer, J. E and Lorz, H. 1988. Embryogenic and callus specific proteins in somatic embryogenesis of the grass, Dactylis glomerata L., Plant Science, 55: 267-79

Hakman, I. Stabel, P. Engstrom, P and Eriksson, T. 1990. Storage protein acculmulation during zygotic and somatic embryo development in Picea abies (Norway spruce), Physiologia Plantarum, 80: 441-445

Jain, A. K and Datta, R. K. 1992. Shoot organogenesis and plant regeneration in mulberry (Morus bombycis Koidz) : factors influencing morphogenetic potential in callus cultures, Plant Cell Tissue Organ Culture, 29 (1): 43-50

Kim, H. R. Patel, K. R and Thorpe, T. A. 1985. Regeneration of mulberry plantlets through tissue culture, Botanical Gazette, 146: 335-346

Laemmli, U. K. 1970. Cleavage of structural proteins during the assembly of the head of bacteriophage $\mathrm{T}_{4}$, Nature, 277: 680-685

Machii, H. 1992. Organogenesis from immature leaf cultures in mulberry, Morus alba L., Journal of Sericultural Science, Japan, 61: 512-519

Mhatre, M. Bapat, V. A and Rao, P. S. 1985. Regenration of plants from the culture of leaves and axillary buds in mulberry (Morus indica L.), Plant Cell Reports, 4: 7880

Murashige, T and Skoog, F. 1962. A revised medium for rapid growth and bioassays with tobacco tissue cultures., Physiologia Plantarum, 15: 473-497

Narayan, P. Chakraborthy, S and Rao, G. S. 1989. Regeneration of plantlets from the callus of stem segments of mature plants of Morus alba L, Proceedings of Indian National Science Acadamy, 55: 469-472 
O'Farrel P.H. 1975. High resolution twodimensional electrophoresis of proteins, Journal of Biological Chemistry, 250 (10): 4007-4021

Oka, S and Ohyama, K. 1981. In vitro initiation of adventitious buds and its modification by high concentration of benzyl adenine in leaf tissues of mulberry (Morus alba L.), Canadian Journal of Botany, 59: 68-74

Ramagopal, S. 1989. Barley proteins associated with tissue differentiation, Journal Plant Physiology, 134: 395-405

Ramgopal, S. 1994. Protein variation accompanies leaf differentiation in sugarcane (Saccharum officinarum) and is influenced by genotype, Plant Cell Reports 6: 692-696

Reynolds T. L 1990. A two-dimensional electrophoretic analysis of protein synthesis and accumulation during adventitious shoot formation in somatic tissue cultures of Solanum carolinense L., Journal of Plant Physiology, 136: 213-218

Stafstrom, J. P and Sussex, I. M. 1988. Patterns of protein synthesis in dormant and growing vegetative buds of pea, Planta, 176: 497-505

Stirn, S and Jacobsen, H. J. 1987. Marker proteins for embryogenic differentiation patterns in pea callus, Plant Cell Reports, 6: $50-54$

Sung, Z. R and Okimoto, R. 1981, Embryogenic protein in somatic embryogenesis of carrot, Proceedings of National Academy of Science, USA, 78: 3683-3687

Sung, Z. R and Okimoto, R. 1983. Coordinate gene expression during somatic embryogenesis in carrots, Proceedings of National Academy of Science, USA, 80: 2661-2665

Thorpe, T. A. 1993. In vitro organogenesis and somatic embryogenesis: Physiological and biochemical aspects. In: (eds.) Roubelakis, K. A., Angelakis and
Tran Thanh Van, K. Markers of plant morphogenesis Plenum Press, New York.

Villalabos, V. M., Leung, D. W. M and Thorpe, T. A. 1984. Light-cytokinin interaction in shoot formation in cultured cotyledon explants of radiata pine, Physiologia Plantarum, 61: 497-504. 